\title{
India's Nationalism in Historical Perspective: The Democratic Dangers of Ascendant Nativism
}

\author{
Maya Tudor \\ Associate Professor of Government and Public Policy, Blavatnik School \\ of Government and Fellow, St. Hilda's College, University of Oxford
}

\begin{abstract}
Does nationalist sentiment support or stymie democracy? And through what mechanisms? As comparative scholars have done little to answer this question, this article draws upon evidence from the Modi government to suggest that the relationship between degree of nationalism and democracy hinges upon a country's dominant type of nationalism. To evidence this theoretical claim, the article develops two empirical arguments: first, that a historically inclusive founding Indian nationalism has been harnessed to protect democratic institutions during political crises and second, that a newly ascendant and exclusive Indian nationalism is legitimating the sidelining of minorities. In doing so, India is embarking upon a path by which established democracies break down.
\end{abstract}

Keywords: nationalism, nativism, democracy, democratic endurance, India

Acknowledgment: The author is grateful to Rani Mullen and two anonymous reviewers for their comments on this essay.

\section{RESUMEN}

¿El nacionalismo creciente apoya o reduce la democracia? ¿y a través de qué mecanismos? Ya que los que los académicos compar-ativos han hecho poco para responder a esta pregunta, el artículo saca evidencia del gobierno de Modi para sugerir que la relación en-tre el grado de nacionalismo y democracia depende del tipo dom- 
inante de nacionalismo en el país. Para evidenciar esta afirmación teórica, el artículo desarrolla dos argumentos empíricos: uno, que un nacionalismo indio fundador e incluyente de la historia ha sido utilizado para proteger a las instituciones democráticas durante crisis políticas y dos, que un nuevo nacionalismo indio jerárquico está legitimando la marginación de las minorías, lo cual es una ruta mediante la cual se quiebran las democracias establecidas.

Palabras clave: nacionalismo, nativismo, democracia, persistencia democrática, India

\section{摘要}

FI 益加 NnKA 主 Ck c431kliELMK 主 ? tTiA k/TT, X klEilrlf4IfiLM?FE-T-bLV*AILT-A Illi4 这 -Airr-q, AK30AIlaZZ*fitti tffxi.1c, FliEt-KA Cf'DI*itK 主 QIsiE n Affx\&-T--A-mn 主要 KA 主 C 类 M. i.1FA -A-1.断言 , AKVAffiTP41 i.1-1.)\#::A-, EPAKA 主 CA-A-) . ..nNATst, -LIM-T-12VPZZtiNtfiLIMIsiEnK 主 fiLf4g; A -, EPAKA 主 C3ditffigilftfittst, -Lihkh-T-ILIn 少 likK AAA-Enst, \#KiffQigaENDAnK .

\section{关 41-i4: KA 主 C, AK.土主 C, Kii, K 主 EFFI)J, EPA}

round the world, nationalist governments are ascendant. The world's most populous countries, as far-flung as China, the United States, Russia, Venezuela, and Myanmar, are led now by governments that purport to represent "the people" but give new primacy to the interests of their ethnic or religious majorities. India was part of this global trend, having elected a Prime Minister in 2014 who ran on a twin campaign of economic reform and religious nationalism.
During India's 2014 election, some observers fretted that India's first overtly Hindu nationalist government would undermine minority rights and with it, Indian democracy, reflecting a belief that nationalism was inherently antidemocratic ideology. ${ }^{1}$ Yet others argued that nationalist fervor has underpinned the construction of welfare states that invest in their citizens ${ }^{2}$ and movements for colonial independence in Americas, Asia, and Africa. ${ }^{3}$ 
So, which is it? Does rising nationalism support or stymie democracy? And through what mechanisms? As comparative scholars have done little to answer this question, this article draws upon evidence from India under the Modi government to suggest that the relationship between degree of nationalism and democracy hinges upon a country's dominant type of nationalism. To evidence this theoretical claim, the article develops two empirical arguments: one, that the substantive tenets of an historically inclusive founding Indian nationalism have been harnessed to protect democratic institutions during political crises and two, that a newly exclusive Indian nationalism is legitimating the sidelining of minorities, one route through which established democracies break down. These arguments theoretically innovate by linking discussions within political theory about the nature of obligations that emerge when individuals view themselves as belonging to a shared national community and comparative ethnicity scholars who have long underscored the pivotal importance of ranked versus unranked ethnic systems in promoting political violence.

The remainder of this article is organized into six sections: the first section will briefly review how scholars have defined and categorized different types of national identity, arguing that nationalism and democracy scholars have developed little theoretical understanding of the relationship between the two; the second section will delve into the Indian case, describing how the dominant narrative of Indian nationalism was predominantly inclusive with respect to its most activated social cleavages at India's founding and that this inclusivity brokered the constitutional compromises that enabled Indian democracy to first be established; the third section will show how the inclusive tenets of nationalism have supported Indian democracy because the four pillars of Indian nationalism aided democrats in the country's most severe political crises-both the mid-1950's struggle over linguistic re-organization and the 1977 election which ended Indira Gandhi's Emergency. The fourth section will review how the mainstreaming of a Hindu national identity, which began in the 1980s but which reached its historical apogee with Modi's election, legitimates the marginalization of political minorities. To the extent that a majoritarian view of Indian nationalism becomes more widely accepted, the breakdown of democracy through the mass arrogation of minority rights becomes more likely. India's national identity is closer toward the type of ethnic majoritarian nationalism evident in neighboring Pakistan and Burma, both countries which have fused the religion of the majority with national identity and which have witnessed the consequent faltering of democracy on the grounds of minority rights.

\section{What's in the "We"? Nationalisms and Why They Impact Democracy}

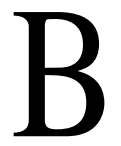
efore arguing that India's inclusive nationalism has historically succored its democracy and that a newly exclusive interpretation of In- 
dian nationalism endangers it, it is important to detour into definitions. $\mathrm{Na}$ tionalism is the principle which holds that the political unit or the state should be congruent with the nation. A nation exists if "members of the category firmly recognize mutual rights and duties to each other in virtue of their shared membership of it." 4 Paradigmatically, nationalism proclaims the supremacy of the nation's claims over other kinds of claims to individual allegiance. Today, all modern states espouse nationalist ideals to define the relationship between itself, its citizens, and the outside world. And all modern states provide exclusive benefits to their citizens. Democracy can denote an ever-expanding list of characteristics, but the three most critical elements of democracy are typically understood to be elections, competition, and a guarantee of universal civil and political liberties for all citizens. $^{5}$

As astonishingly little comparative research has explicitly probed the relationship between nationalism and democracy, this article seeks to theorize the repercussions of a shifting nationalism - from historically inclusive to increasingly exclusive-in the single case of India. In this article, I suggest important differences in and impacts of nationalist types. I posit that, to the extent that all citizens can choose to participate in and identify with the nation by subscribing to specified principles, a nationalism can be said to be formally inclusive. ${ }^{6}$ By contrast, to the extent that national identity is formally denoted by an ascriptive identity (which is not limited to ethnic cleavages and includes religion in much of the world), the more exclusive are such founding national narratives because they marginalize citizens without such identities. ${ }^{7}$ That these theoretical distinctions may be blurred in our empirical observations does not obviate their theoretical usefulness. Just as scholars of comparative ethnicity make distinctions between ranked and unranked ethnic systems, such categorizations support attempts to comparatively analyze nationalisms across countries and within single countries across time. ${ }^{8}$

I propose that founding narratives of nationalism can impact the functioning of democracy through two mechanisms: first, because such narratives provide legitimating ideational resources to politicians, particularly in moments of crisis and second, because such narratives can become codified in institutions that themselves structure contemporary political outcomes. Although the nation itself may well be an "imagined community" or an "invented tradition" 10 open to re-negotiation across time, the content of national identity is rarely in constant flux. Founding narratives are fundamentally formed at the moment the nation is articulated, in ways that tend to be sticky across timein most of the post-colonial wars during the struggle for national independenceand tend to endure unless reshaped at a subsequent critical juncture such as a war or military coup. ${ }^{11}$

Developing this theoretical framework, through the case of India, helps to advance comparative theoretical debates in three ways. First, theoriz- 
ing the relationship between democracy and nationalism moves comparative scholarship, which largely explored the origins of national identities, towards a focus on the effects of different types of national identities. While comparative scholars of nationalism agree that all nationalisms share a claim to individual allegiance and promote the legitimacy of prioritizing its own citizens over noncitizens, scholars have long understood that nationalisms differ in type. Studying the historical emergence of the nation in Europe, political theorists have argued that two types of nationalism come into being at founding moments: a liberal "civic" nationalism consisting of any like-minded group of people aspiring to a state-like organiza-tion ${ }^{12}$ and an "ethnic" nationalism that uses nonvoluntary characteristics such as ethnicity or language as the basis for common origin. ${ }^{13}$ Yet little work has sought to examine the effects of different types of nationalism.

To be sure, empirically categorizing nationalist types is challenging because competing narratives of nationalism exist within every country. Yet everywhere that a state has witnessed a stable politics, a country can be said to have a dominant narrative. ${ }^{14}$ Indeed, foundational studies of nationalism have labeled French nationalism as predominantly civic (Liberté, Egalité, Fraternité) and German nationalism as predominantly ethnic (Blut und Bo-den). These classifications can be used to make distinctions beyond Europe: Malaysia and Sri Lanka enshrined classic ethnic classifications within their national identities when their modern nations were formed, while Indonesia embraced a civic creed (Pancasila) as the basis of national belonging.

A second theoretical contribution of this article is to begin charting out the kinds of ideas that help political actors to install and protect democracy. Comparative democratization scholars have shown that a wide array of factors systematically impact democratization and democratic endurance. The oldest and most influential argument in this vein is that material differences between class groupings drive democratization and democratic endurance. ${ }^{15}$ Such explanations for democracy are hyperrationalist however, assuming that forward-looking voters with full information organize politically and cast ballots driven almost exclusively by material self-interest.

Recent work in political science has begun to take seriously the claim that ideas fundamentally shape political choices. One investigation exploring competing theses for the contemporary rise in nativist nationalism in Europe finds that ideational narratives better predict the patterns of support for nativist nationalism than economic inequality ${ }^{16}$, while another book finds that the predictive power of material inequality for democratization has declined across time $^{17}$ Research suggesting that economic inequality drives the intensity of nationalist identification does not probe whether different types of nationalism impact democratic endurance. ${ }^{18}$ Thus, this article theoretically supplements the dominant scholarly focus upon how material inequalities 
can explain democratization and democratic endurance with an understanding of how types of ideational inequalities, specifically in the form of national narratives, can impact democracy.

Third, this article expands upon the recent scholarship in political science that has taken nationalism seriously as a causal force for outcomes other than democracy. When the nation is defined in relatively inclusive terms through a nation's "founding narra-tive," 19 scholars have suggested that a wide array of virtuous political outcomes becomes more likely: the provision of more public goods, ${ }^{20}$ incorporation of immigrants from ethnic and religious minorities, ${ }^{21}$ the protection of minorities from mass killing or geno-cide. ${ }^{22}$ While nationalism as a causal force is gaining attention, political scientists have yet to establish whether nationalism's types impact the long-run possibilities for creating representative forms of government.

\section{India: An Historically Inclusive Nationalism and Exceptional Democracy}

I ndia's enduring democracy has long puzzled political scientists, as it comprises an unusual case of democratic stability among low-income countries. Among the factors said to contribute to the success of India's stable democracy are its unusually developed nationalist movement ${ }^{23}$ and the unusually inclusive national identity evolved by the anticolonial movement during the first half of the twentieth century. ${ }^{24}$ As late as 1931, Winston Churchill famously retorted, "India ... is a geographical term. It is no more a united nation than the Equator." 25 As the urban, educated elite employed in the colonial state began to seek greater indigenous representation in government in 1920s, they began to espouse a more inclusive nationalist identity that would strategically advance their own material interests. ${ }^{26}$

As articulated by its anticolonial movement, Indian National Congress, each of India's four pillars nationalism was inclusive. The first dimension through which Congress' nationalist narrative was inclusive was that it publicly rejected all public recognition of caste hierarchies. Nineteenth-century India was characterized by a caste-saturated social fabric in which an indi-vidual's caste status was reinforced in most social interactions. The all-encompassing and hierarchical nature of caste identities precluded the possibility of individuals engaging on equal terms compatible with citizenship. $^{27}$ Beginning in the 1920s, Congressmen mobilized against public recognition of caste hierarchies on places such as roads and wells, ${ }^{28}$ with the goal of melding together a national community that could claim to represent all Indians. Doing so was crucial to refuting the ideational basis of colonial rule. ${ }^{29}$ Mohandas Ka-ramchand Gandhi's early interventions into politics, his ashrams, and eventually Congress altogether under his leadership intensively engaged in "village uplift" activities, such as providing basic sanitation and educational programs that not only did not discriminate by 
caste (a revolutionary idea at the time) but actively engaged predominantly high-caste nationalist leaders in the public rejection of caste hierarchies. ${ }^{30}$ Public programs which consistently and symbolically violated caste hierarchies helped to create the very possibility that caste hierarchy could be subsumed to a national identity.

Social egalitarianism with respect to caste enabled the nationalist movement to stay unified over its decades-long struggle. As political scientists have repeatedly argued, well-organized institutions have directly driven political stability across the post-colonial world. ${ }^{31}$ The social egalitarianism of the Congress national movement also directly led to the eventual institutionalization of the political egalitarianism (universal adult franchise and universal political and civil liberties) that defined democracy. ${ }^{32}$ The colonial desire to divide and thus delegitimate Indian nationalist movement motivated it to propose separate electorates for Muslims in 1909. To forestall a similar attempt to create a separatist political organization among lower-caste Hindus, Congress mainstreamed universal adult suffrage as Congress policy in its 1931 Karachi Resolution. When the colonial regime announced the Communal Award in 1932, which suggested separate electorates for lower castes. Should this policy become law, it effectively cleave off lower-caste Hindus from political mobilization and thereby further undermine Congress' claim to represent a national community. The strong reaction, specifically Gandhi's "resolved fast unto death," created pressure to among the leaders of the lower-caste communities relinquish separate electorates in favor of caste reservations. The eventual compromise-universal adult franchise and the rejection of separate electoratesrepresented a strategic accommodation between myriad social communities, one in which a national identity was carefully and deliberately constructed to be open to all religious, caste, class and regional communities. ${ }^{33}$

A second way in which India's founding nationalism was inclusive was with respect to the choice of language. In a country that spoke over a thousand languages and in which upward of thirty languages were spoken by a million people or more, the nationalist movement attempted to maximize engagement in the national movement by creating 21 linguistically homogenous regions in 1920. Organizing through local languages rather than just in English encouraged broad participation in the nationalist movement and intimated, first indirectly and later directly, the possibility that these different languages would gain formal recognition in an independent India. Congress made no effort to exclude particular regional tongues from the nationalist movement and explicitly rejected the use of a single national language, which would have politically and economically advantaged the northern Hindi belt of the country. ${ }^{34}$

A third way in which the national movement was inclusive was by embracing a secular character that clearly separated the nation from religious identity in a country that was 
three-quarters Hindu. Secular ideals were initially written into Congress' founding charter, both because nationalist leaders were transplanting the liberal ideals of their English education to an Indian context and because it was strategically beneficial to do so. ${ }^{35}$ While many Congress leaders were themselves Hindus and deeply involved in Hindu reform movements, Congress' policy by 1931 was that it would adopt no constitutional policy to which a majority of either Hindus or Muslims objected and that no Indian citizen should suffer any discrimination "by reason of his or her religion, caste, creed, or sex." ${ }^{36}$ While there was debate among nationalist leaders about the degree to which anticolonial mobilization should engage religious ideals and symbols and while Gandhi's success as a nationalist leader was built on his successful re-interpretation of Hindu devotional discourse,${ }^{37}$ it is notable that Gandhi chose to anoint a wholly secular successor in the form of Jawaharlal Nehru and that the nationalist movement unambiguously rejected any codification of or overt reference to Hinduism as defining of national identity.

A fourth way in which the nationalist movement was inclusive was with respect to its embrace of universal swaraj, or the principle of nonviolent self-determination. ${ }^{38}$ India's most preeminent nationalist leader Gandhi understood this to be the most central aspect of Indian nationalism, ${ }^{39}$ namely the right to non-violently protest in matters of truth and conscience. This conception of Indian nation as a community with a shared commitment to non-violently protest wrongs enabled participation by a broad range of class actors in mass mobilization without fear of violence or loss of property. During the three major anticolonial mobilizations, nationalist leaders regularly stressed that the only condition for participation was that the mobilization remain nonviolent. In the brief text of the resolution announcing the start of the Quit India movement, for example, nonviolence was mentioned on six separate occasions. The national leadership calculated that rural peasantry at all levels of wealth and social status could successfully participate in the anticolonial protest without invoking the class conflict that could fracture fragile national unity.

\section{How Inclusive Nationalism Sustained Indian Democracy}

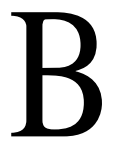
oth right after independence and during the periods of deep political crisis, these inclusive dimensions of Indian nationalism - public caste rejection, secularism, multilin-gualism, and nonviolent self-determi-nationhelped to sustain Indian democracy. As I have written elsewhere, these dimensions of Indian nationalism and their institutionalization within the nationalist movement before independence spurred the nationalist leaders to create a constitution enshrining the key feature of democracy, namely the decision to enshrine elections based on universal adult franchise within the Indian constitution after independence. ${ }^{40}$ Specifically, Congress leaders, comprising an elite demographic, could have cho- 
sen to limit adult suffrage through some land or literacy qualification. Yet Congress leaders had organized mass political support through popularizing an inclusive Indian nationalism through the anticolonial struggle. Limiting the franchise would therefore have required reneging on promises to include a range of minorities - women, Muslims, Dal-itsat a clear cost to lower caste sup-port. ${ }^{41}$ There was little to gain from retreating from these inclusive definitions of the Indian nation. The nonviolent selfdetermination aspect of the national identity had successfully limited mass violence during the anticolo-nial struggle. Thus, the Congress-dominated Constituent Assembly was able to codify general election's universal adult suffrage within the Indian constitution after independence.

Some may object that the Indian constitution cannot rightly be labeled inclusive because it allowed for positive discrimination for certain caste categories such as Scheduled Tribes, Scheduled Castes (as well as more recently, Other Backward Classes) and because it rejected a uniform civil code. However, few scholars would dispute that the express purpose of these constitutional clauses, read in the social context of the time, was specifically to provide for the greater inclusion of marginalized social groups. ${ }^{42}$ The single strongest constitutional nod toward majoritarianism may have been the directive principle to prevent cow slaughter. Constitutional drafters included a constitutional provision for cow protection (albeit justified on economic development rather than religious grounds) in order to gain the assent of Hindu nationalists for the constitution. At the same time, the constitution clearly rejected any legal recourse for this Hindu majoritarianirective. ${ }^{43}$ The remainder of this section will examine the role that Indian nationalism played in the two moments of deepest internal political strife in India, moments when the democratically popular solution to the crisis was not aligned with the interests of its Prime Ministers-the agitation over linguistic states and the abrogation of civil liberties during Indira Gandhi's 1975-77 Emergency.

India's thorniest problem in the decade after independence was not the creation or adoption of its constitution, but questions concerning language along two dimensions: whether to select a national language and whether to re-organize colonial states along linguistic borders. These contentious issues were ultimately resolved in extraordinarily egalitarian fashions when compared to how national liberation movements around the globe addressed these similar questions: through the selection of many official languages and through the creation of new linguistic states. To arrive at those decisions, proponents of these outcomes employed key elements of the inclusive national identity to legitimate their causes, thereby helping to sustain Indian democracy.

The question of what language to select as a national language for India animated the closing and most contentious months of India's Constituent Assembly, with an initial proposal tabled 
to make Hindi, the language spoken by approximately $40 \%$ of the country, India's sole national language. This proposal had support from many leaders of the nationalist movement, including Gandhi and Rajendra Prasad, but was opposed by the primarily southern states which did not use Hindi and would thus be relatively disadvantaged by its adoption relative to the northern states. Speaking at the Constituent Assembly debates, Shri Chettiar stated, "Those whose mother tongue is Hindi they learn only Hindi. But, we in the South, we have got to study not only Hindi but also our own mother tongue; we-cannot give up our mother tongue. There is also the regional language; we have to study that. Permanently, forever, you are handicapping us by this arrangement." Speaking at these debates, Shri Munavalli stated, "Language means the very life-blood of the nation ... [so] in settling language questions, mere theory of [majority-rules] democracy must not prevail." 44 Concerns about linguistic majoritarianism led to the eventual solution, codified in Article 343 of the Constitution, which adopted Hindi and English as dual official languages of the Union, with a 15-year sunset clause for English which has been indefinitely extended since.

The contentious issue of whether to officially recognize regional languages by creating new linguistically-coherent states was a divisive issue. The debate over linguistic states was one of the few issues which was resolved by the adoption of a policy clearly opposed by its first and arguably most powerful Prime Minister. The success of the mo bilization was driven in no small part by invoking the inclusive pillars of the nationalist movement.

During the independence struggle, India's nationalist leaders had regularly promised to create new, linguistically homogenous states and legitimated protest. Congress had re-organized itself along linguistic lines in 1920 in order to achieve mass popularization and regularly promised linguistic re-organization during the nationalist struggle, including in its 1946 election manifesto. After independence was achieved however, Congress leaders wished to renege upon their earlier commitment to linguistic self-determination because they felt that linguistic re-organization of states would threaten national unity. In a post-Partition environment that witnessed states seeking to secede from the Union of India, Congress leaders worried that linguistic re-organization of states would further inflame separatist tendencies. Prime Minister Nehru and other members of the nationalist high command-Pa-tel, Prasad, Rajagopalachari, and even Ambedkar-were cloaked with significant legitimacy forged in the fires of the independence struggle and opposed any linguistic re-organization of states on the grounds that it would encourage these secessionist tendencies.

Rather than rejecting linguistic reorganization out of hand however, the government sought to employ a policy of deferral, appointing successive commissions to investigate the possibility of re-organization. But Nehru ultimately and reluctantly concluded that 
linguistic re-organization was necessary after the political supporters of state reorganization employed nationalist tactics to legitimate their demands. The 1948 Dar Commission recommended that the reorganization of provinces should be delayed in accordance with a desire for national unity and that the creation of "provinces on exclusively or even mainly linguistic considerations is not in the larger interests of the Indian nation." ${ }^{\circ 5} \mathrm{~A}$ subsequent report, published in 1949, acknowledged that Congress had previously "given its seal of approval to the general principle of linguistic provinces" but that it was nonetheless "incumbent upon us therefore to view the problem of linguistic provinces in the context of today. That context demands, above everything, the consolidation of India and her freedom. ... [and] demands further stern discouragement of communalism, provincialism, and all other separatist and disruptive tendencies." 46

Because the nationalist leaders had preached and practiced participatory nonviolence in achieving political objectives and because the foremost proponents of linguistic organization appropriated Gandhian language and methods, it was difficult for the government to reject the creation of new states while respecting the fundamental ideals of democratic self-determination that had been an animating claim of the recently successful nationalist movement. For Nehru, two contradictory elements of the national identity were at stake in the states' reorganization issue-national unity on the one hand and the principle of democratic self-determina tion on the other. Nehru's opposition to the movement for linguistic re-organization stemmed from a commitment to national unity, but his concession creating linguistic states ultimately grew out of the deep commitment to the inclusive ideals of the nationalist movement, including the right to non-violently protest government policies. It was for this reason that the 1949 report left a window open for future accommodation, because nationalist leaders themselves were ideationally steeped in the value of self-determination: "However, if public sentiment is insistent and overwhelming, we, as democrats, have to submit to it ... [Emphasis added]." ${ }^{.47}$

This Report failed to mollify the advocates of linguistic re-organization however, and by the early 1950s, it was clear that there was insistent and widespread public support for linguistic re-organization of states by regional leaders and through them, by a broader public. Privately, Nehru deplored the linguistic movement and fervently hoped to leave colonial state boundaries intact. Publicly however, he said that he would eventually accede to its demands at a later date if the all regional leaders agreed. Not to do so would contradict the principle of self-determination for all that Nehru and other Congress leaders had positioned as central to the claim for an independent India.

The most vigorous advocate for linguistic reorganization were Telugu speakers who petitioned, marched, and ultimately used Gandhian hunger-fasts to force the national government to create modern-day state Andhra 
Pradesh. In 1951, after a succession of petitions and protests, a former Congressman went on a five-week hunger strike, which intensified pressure. In May 1952, Nehru said before Parliament, "Even though the formation of linguistic provinces may be desirable in some cases, this would obviously be the wrong time. When the right time comes, let us have them by all means." ${ }^{48}$ In October 1952, a Gandhi associate Potti Sriramalu undertook a fast unto death for the creation of a separate state of Telugu speakers to protest the vague equivocations of both the Prime Minister and the Chief Minister of Madras. Sriramalu was a Gandhi associate who had not only spent time at Gandhi's ashram but had also spent 18 months in jail for his participation in the 1940-41 civil disobedience campaign.

Though Nehru's opposition to linguistic re-organization was steadfast, he gave away when protests employed the nationalist discourse and tactics to legitimate their cause. . On December 3, Nehru wrote in a letter: "Some kind of fast is going on for the Andhra Province and I get frantic telegrams. I am totally unmoved by this and propose to ignore it completely." Nine days later, as these protests and publicity grew, Nehru wrote to the Chief Minister of Madras Rajagopalachari and conceded that the time had come to accept the demand for the Andhra state, "Otherwise complete frustration will grow among the Andhras and we will not be able to catch up with it." 49 Though Nehru had privately conceded that he would have to eventually accept the concept of linguistic states, the death of a former
Gandhi associate Sriramalu a few days later forced Nehru to concede the principle earlier than he anticipated. On December 15, 1952. Sriramalu's death led to the breakout of large-scale protests. The very next day, Nehru publicly announced that the state of Andhra would come into being. In 1954, the States' Reorganization Commission (notably composed of non-Congressmen) was created to make general recommendations for new states and in 1956, Nehru accepted SRC Commission's recommendation to organize a variety of new states along linguistic lines, setting in motion the redrawing of the Indian map along linguistic lines, a process that continues to the present day.

At a time when Nehru's position on every major issue became governing policy, it is instructive to examine a case when the Prime Minister adopted a policy that he clearly opposed. That issue was one in which the fundamental definition of the nation as an inclusive one and in which individual and collective rights to non-violently protest for their view of justice was at stake. Nationalist ideals were employed to legitimate opposition mobilization for linguistic re-organization. In Pakistan at this time by contrast, popular protest for language autonomy was forcibly put down, ultimately resulting in what some scholars have called a genocide and the breakup of that country. ${ }^{50}$ In India, where explicitly inclusive national ideals were suffused and legitimated throughout the national movement, forcibly putting down peaceful protests would have entailed repudiating the cornerstones of the nationalist move- 
ment ideals. Instead of refuting the legitimacy of these demands through violent repression then, India's first government attempted a policy of delay, and when this was unsuccessful, accommodated these demands. Because the government was clearly opposed to this policy, it is difficult to escape the conclusion that effective use of nationalist rhetoric and tactics were pivotal in motivating the government's volte-face.

India's inclusive nationalism also helped to end the greatest challenge to India's democracy to date, Indira Gandhi's 21-month suspension of civil and political liberties between June 1975 and March 1977. The Emergency, as it was known, was perhaps the closest that India came to ending its democracy. Here, as in the case of the linguistic states, the inclusive ideology of the nationalist struggle was used by political opposition to effectively rally support for ousting the incumbent and thus formed an important resource for opposition democrats.

Following Prime Minister Jawaharlal Nehru's death in 1964, Lal Bahadur Shastri succeeded Nehru, but this successor's sudden death in 1966 led Congress' powerful and conservative state-level leaders to choose Indira Gandhi for the Prime Ministership primarily because she was viewed as a pliant figurehead. Unexpectedly, Indira Gandhi followed in her father's footsteps and asserted her power, which led to a split in the dominant: a break-away socialist Congress faction acknowledging Indira Gandhi's leadership and an old guard of conservative party bosses who maintained the original Congress Party networks.

In order to consolidate her rule in the absence of reliable party support, Indira attacked institutional constraints on her rule while still maintaining and even elevating inclusionary appeals to the Indian masses. In the 1971 national election, fresh on the heels of a popular intervention to help East Pakistan become Bangladesh, Indira Gandhi employed a populist campaign slogan of garibi hatao (abolish poverty) which successfully appealed directly to the numerically larger and socio-economically subordinate lower castes. After Indira succeeded in winning a large electoral mandate, one of her first acts was to undermine the judiciary by passing the $24^{\text {th }}$ and $25^{\text {th }}$ constitutional amendments, which controlled constitutional amendment procedures and eliminated protections for those negatively impacted by nationalization programs. Under the pretense of addressing unrest instigated by the political opposition, Indira declared a state of emergency in which civil liberties and political freedoms were suspended. During this time, many members of her political opposition were arbitrarily arrested and personal freedoms were widely curtailed.

Two aspects of Indian nationalism-a commitment to procedural (now constitutional) means of resolving conflict and the broad acceptance of the right to dissent-were effectively harnessed by Indira Gandhi's political opposition to end the Emergency once Indira Gandhi had decided to hold a general election. Though the leaders of 
the Janata opposition coalition tailored their messages to their specific audiences, the most consistent messages during the electoral campaign centered upon the right to dissent freely in a democracy, often in ways that echoed the nationalist movement. ${ }^{51}$ For example, a Gandhian associate Jayprakash Narayan said in an election rally "It was Mahatma Gandhi who taught this country not to be cowed down by atrocities and to stand up fearlessly against threats and intimidation. ${ }^{152} \mathrm{~A}$ defector from Indira Gandi's government, Jagjivan Ram, said "when India became free, we decided that there would no more be the rule of the rajas and maharajas. We decided that every citizen of India, irrespective of class, caste and community, would be equal .... In the last 19 months we have seen people's rights being abridged and the Constitution being abridged and all kinds of evils creeping into the body politic of the country. That is why I have decided to resign ....53

Indira Gandhi did not attempt to manipulate the election in any way, as was done just weeks previously in neighboring Pakistan, in itself a testament to the ideational hegemony of democratic elections as the arbiter of political legitimacy.

The 1977 election ending Indira's rule was not so much a shift of previous Congress voters to the opposition as it was of previously apolitical citizens voting for Indira's opposition by a huge margin. As Myron Weiner writes, "Janata party candidates campaigned on a single issue: ending the emergency and restoring democracy to India. Econom ic issues were secondary, except insofar as they illustrated the problems that arose when individuals were deprived of their rights to protest. ${ }^{54}$ The opposition Janata Party gained the largest percentage of votes ever gained by a non-Congress Party and Congress even lost the election in its regional stronghold of Uttar Pradesh. Because all other causes were secondary to defeating Indira's democratic assaults, Bharatiya Jana Sangh joined this grand anti-Indira coalition. This was the first time that Hindu nationalists came to power became part of India's national governing coalitions.

In sum, India's democracy was endangered during the 1975 Emergency by the repression of civil and political rights. The decisive rejection of Indira's autocratic turn in 1977 both hinged upon and ultimately re-affirmed inclusive and democratic nationalism. The right to nonviolently protest legitimated the opposition in India's most pivotal election to date. Indira lost power because "the Indian electorate cared more than she thought for democratic institutions. ${ }^{155}$ The nationalist ideals of the right to protest had formed a democratic resource for opposition.

\section{Shifting National Narratives: The Rising Threat under the Modi Government}

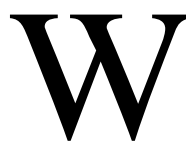
hile it is over a century old, political majoritarianism in the form of Hindu nationalism is witnessing a new mainstreaming under the Modi government that, to the 
extent it gains broader public acceptance, poses dangers to Indian democracy. In the long term, the majoritarian re-interpretation of Indian nationalism may legitimate, as it has in neighboring Burma, a more systematic deprivation of minority rights.

Religious nationalism in India is at least a century old. It was made possible when an organizing bodyfor Hinduism (Hindu Mahasabha) was first established in 1914. The political beginnings of Hindu nationalists started in the early 1920s with the publishing of several key treatises and the creation of an organized hybrid political and cultural movement, the Rashtriya Swayamsevak Sangh (RSS). ${ }^{56}$ Its main political outlet was the Bharatiya Jana Sangh, formed in 1951 and reestablished as the Bhara-tiya Janata Party (BJP) in $1980 .{ }^{57}$ Hindu nationalists' core contention has been that the South Asian subcontinent has been historically Hindu and thus contends that Indian nationalism should be based upon and promulgate Hinduism.

Historically, the cultural nationalists were a relatively marginal force in both constitutional deliberations and in Indian politics generally throughout the post-independence decades. An important opening for a political expansion of the Hindu nationalist agenda arose with the decline of Congress dominance and with the Congress party's foray into ethnic nationalism, particularly evident in the heavy-handed repression of cultural and religious separatism in both Punjab in the 1980s and in Jammu and Kashmir in the 1990s.$^{58}$ Beginning in the 1980 s, the
Hindu nationalist movement was rejuvenated as it agitated for the creation of a temple to mark the birthplace of Ram near the Babri mosque in Ayodhya, known as the Ramjanmbhoomi movement. This movement accompanied the BJP's spread into many more towns and villages and helped support the BJP's win in India's largest state of Uttar Pradesh. ${ }^{59}$ The mosque on the alleged site of Ram's birthplace was torn down in 1992, which resulted in nationwide rioting and the deaths of at least 2000 people. $^{60}$

When the BJP came to national power in 1996 (briefly) and in 1998 (for a full-term), the BJP led such a large coalition government that it had limited space to promote a Hindu nationalist agenda. ${ }^{61}$ Indeed, the party itself represented a diverse set of goals/aspirations: Hindu nationalism to its historical core constituency: political power to Other Backward Classes (OBCs) to newly organized middle castes and access to social services for lowest castes. ${ }^{62}$ It was during the BJP's first full-term national government that communal rights broke out in 2002 in the state of Gujarat however. During Narendra Modi's tenure as Chief Minister, India witnessed the worst outbreak of communal violence since independence, one that led to the deaths of approximately 1000 lives. $^{63}$

The BJP lost power in 2004 and returned to power in 2014 under Modi's leadership. During its most recent national campaign and now in power, the Modi government has sought to use and alter Indian nationalism in two 
ways that are ultimately likely to cause democratic backsliding in India. The first way in which the Modi government is unraveling the democratic fabric laboriously knitted during the Indian nationalist movement is that his campaign and now government has consistently and on multiple fronts sought to equate the majority religion with the national identity. Specifically, the Modi government has undertaken to re-interpret the Indian nation as Hindu, and critically, to always have been Hindu.

A selective tendency to associate India with Hinduism (in regions where doing was politically profitable) was already in evidence on the campaign trail where billboards overtly linked Modi, nationalism, and Hinduism together in a trinity that marked a departure from the largely secular rhetoric of past campaigns. ${ }^{64}$ Across Mumbai, for example, billboards proclaimed, "I am a patriot. I am a Hindu nationalist." $"$ Modi's speeches on the campaign trail were peppered throughout with Hindu references. And in places where it effectively divided vote banks, Modi alleged that the incumbent Congress government provided subsidies for meat export and thereby promoting cow slaughter, an offensive act to Hinduism that he termed a "pink revolution." 66

Just as importantly in a country with a high degree of illiteracy, Modi appropriated visibly Hindu symbols on important state and electoral occasions. Modi borrowed the language of inclusive cloth nationalism that was so important in the nationalist movement but adapted it to specifically denote the majority community ${ }^{67}$ During the most important and visible speeches of the campaign, Modi wore saffron, the color of Hinduism. Modi often prayed at sacred Hindu spots before election rallies and appeared at speeches accompanied by Hindu priests. He contested his electoral seat from the spiritual heart of Hinduism, Varanasi. And the BJP election manifesto proclaimed that the BJP would search for "all possibilities within the framework of the Constitution to facilitate the construction of the Ram Temple in Ayodhya," an issue which sparked nationwide religious riots. ${ }^{68}$

Perhaps most invidiously however, Modi's campaign argued that India had always been a Hindu nation, which was in evidence in the campaign over the debate over whether Nehru or Patel was the more legitimate founding father. The BJP under Modi's leadership has systematically undertaken to recognize one of the more conservative nationalist leaders, Vallabhbhai Patel, as a more venerated founding father, while minimizing the contributions of the first Prime Minister Jawaharlal Nehru. ${ }^{69}$ The veneration of Patel cast a historically secular Indian nationalism in a more Hindu light and cloaked Modi in a mantle of historical legitimacy while eliding the fact that Patel, though a staunch nationalist who was relatively hawkish in foreign affairs and closer to Hindu organizations, wholly hewed to the Congress policy of secularism and banned the RSS, the organization that was both responsible for Gandhi's assassination and formed the manpower to deliver votes for the Modi campaign. 
Once in power, despite some commentators' view that Modi was an ideological moderate who stood first and foremost for economic development rather than Hindu nationalism, the Modi government's projection of India nation as Hindu has consistently defined the rhetoric of the government, though studiously not Modi himself. To be sure, economic development is a core element of Modi's political program, but so too is his commitment to Hindu nationalism. ${ }^{70}$ As stated above, political movements to protect cows against slaughter are not new and date to the turn of the nineteenth century. However, cow protection has not been as central to any government's policies as it has been to Modi's. Modi explicitly campaigned on the promise to introduce a ban on beef, a promise that represented the Hindu right-wing (since $70 \%$ of the Indian population eats meat), and he followed through on that promise. Gujarat, Modi's home state, first banned the slaughter of cows upon Modi's election and second tightened the punishment, making cow slaughter a crime subject life imprisonment. Eighteen other states have followed suit until the Supreme Court recently struck down such laws. The effect of this policy, undertaken to cater to Modi's Hindu nationalist base, is to deprive the lowest and disproportionately Muslim and Christian strata of society of important sources of income. In several cases, Hindu nationalist groups have killed individuals accused of slaughtering cattle or selling beef. In every one of these instances until last year, Modi himself studiously avoided condemning the violence. Last year, Modi only spoke up to condemn violence once a video surfaced showing Hindu Dalits being beaten up for skinning cows, causing a backlash in the Dalit community. ${ }^{71}$

To create a veneer of plausible deniability for the rise of the Hindu nationalist agenda, Modi focuses heavily on the economic development agenda and avoids comments that directly assert Hinduism to be the only legitimate religion of India. However, Modi has just as studiously avoided condemning the frequent instances when high-ranking members of his government have made precisely that connection. In 2014 for instance, one of his ministers told a rally in New Delhi that citizens would henceforth have to choose between a "government of followers of Rama [a Hindu god] and a government of bastards." This Minister kept her job. ${ }^{72}$ Perhaps more stunningly, when the BJP recently won a resounding victory in state elections of Uttar Pradesh, a state that would form the world's sixth largest country if it were sovereign, Prime Minister Modi chose a saffron-clad Hindu priest known for his virulent opposition to Muslims to become Chief Minister. Chief Minister Yogi Adityanath has over a dozen criminal charges pending against him, including attempted murder and has consistently made such controversial statements such as "there is no difference between the language of [popular movie star] Shah Rukh Khan and [Pakistani terrorist leader] Hafiz Saeed" or "I will not stop until I turn India and UP into Hindu rashtra [state]."73 
The Hindu nationalist agenda under Modi's government is also in evidence through the sustained attempts to re-write Indian history as one of aHindu nation. This is perhaps more worrisome because it is less visible and because it reflects the main channel through which national identities are popularized. The saffronization of In-dia's education curriculum began under the Vajpayee government. $^{74}$ But the heightened intensity and centrality of this program to Modi's government is new. Unlike the Vajpayee government, the project to alter educational curricula reached is now directed from the national center without the constraint of a coalition government to manage. Within four days of the national election victory in 2014, the government announced plans to rewrite textbooks for Indian schools. States where the BJP is strongest are witnessing the strongest attempt at so-called saffronization. Some of these changes argue, for example, that the first airplane was invented in India by the Hindu god Ram. ${ }^{75}$ Creating a new national holiday to honor a key Hindu figure, protesting the right of non-Indian scholars to independently assess Indian thought, omitting the word "secular" from the preamble to the Indian constitution on National Day, removing Gandhi's image from the symbol of Khadi and Village Industries Commission and replacing it with an image of Modi, the renaming of Muslim streets, the removal of Muslim names in textbooks, and the omission of the Taj Mahal from the UP tourist brochures are among the many other ways that history is being re-written to erase a history of syncretic religiosity and to fuse the conception of the Indian nation with Hinduism.

The private or even civic celebration of any social identity, including religion, is not problematic for democracy in and of itself. Identities are important vehicles of creating community. But for a national government to actively seek to define the nation through "Hinduness" poses democratic dangers because, to the extent that Hinduism is broadly understood to be the true and authentic basis of citizenship in India, this will authorize governments to deprive religious minorities of civil and political rights. This is indeed exactly what has happened in Burma, a neighboring country where discrimination against religious minorities has been accepted as right and proper by a large proportion of the population specifically because the national identity has been inextricably defined by the religion of the majority. ${ }^{76}$ While the political repercussions of this moment may not become immediately apparent, subsequent moments of political crisis can form prime opportunities for political entrepreneurs to scapegoat minorities because they are "rightly" assumed to be second class citizens less deserving of such rights. There is already tentative survey evidence that the "middle ground" of public opinion in India is shifting toward accepting majoritarianism. ${ }^{77}$ To the extent that the Indian national identity becomes broadly accepted as fundamentally Hindu by the wider public then, the Indian public will be more willing to accept scape-goating as legitimated by a "natural" political order. 
The second way in which the Modi government is eroding India's democratic fabric is that his government is seeking to label any dissent as antinational or unpatriotic, which poses a clear danger to the civil and political liberties that are democracy's cornerstone. A prominent example of this is the hanging and subsequent protests surrounding the hanging of Afzal Guru, the prime suspect in the 2001 terror attack on the Indian parliament. When students at one of India's most prominent universities protested his hanging on the grounds of concern over due process, ${ }^{78}$ three students were arrested on accusations of being antina-tional and assaulted en route to court with their lawyers in the plain view of the police. These events were used to cast the entire left-leaning university as a hotbed of antinational agitation. ${ }^{79}$ Subsequently, the national head of the BJP party Amit Shah called the leader of the opposition Congress party, Ra-hul Gandhi, antinational because he supported the right of these students to protest. Through such actions, the important distinction between finding something politically offensive and illegal is being steadily eroded, with the might of the state taking sides to silence dissent. As Levitsky and Ziblatt have recently argued, questioning opposition's very right to dissent is one of the two most frequent routes by which established democracies break down. ${ }^{80}$

BJP leaders are labeling as antinational any protest against the government across a wide range of domains: against antinuclear activists, foreign NGOs, ${ }^{81}$ cricket fans who cheer for $\mathrm{Pa}$ kistan at games, ${ }^{82}$ and the leaders of major opposition parties. ${ }^{83}$ Police in Jammu and Kashmir recently arrested four youth for standing when the Pakistani national anthem was played at a cricket match, a clear transgression of freedom of expression. ${ }^{84}$ Indeed, the Modi government is pursuing the mantra of "if you are not with me, you are anti-na-tional." ${ }^{85}$ As the state clamps down on civil and political liberties to defend a nationalism that it alone can define, the power of nationalist fervor is directed in ways that the state alone can target and direct. Historically, this has been precursor to increasingly authoritarian forms of government. It is not for nothing that 65 former bureaucrats recently published an open letter stating that India is seeing a "growing hyper-nationalism that reduces any critique to a binary that if you are not with the government, you are antinational" $" 86$ and calling for a defense of the secular Constitution, was as envisaged by the founding fathers.

So what does this shifting conception of Indian nationalism portend for Indian democracy? Drawing on comparative studies of democracy's demise globally, the failure to wholeheartedly reject political violence and a readiness to curtail civil liberties of political rivals for electoral gain are among the most worrisome signs for the health of any democracy. ${ }^{87}$ There is little doubt that these tendencies are in evidence in India today. When core membership in the nation is religiously defined, one needs little imagination to understand when the wholesale violence directed toward religious minorities is more possible and even 
accepted as natural. For democratic procedures and norms to endure, political rivals must accept that opposition has a right to criticize and to protest policies. Democratic disagreement is not always civil and may indeed sometimes resemble a "hot family feud." ${ }^{88}$ But a key pillar of democratic stability bargain has always been that all citizens form a national family. more likely.

Elites in that extended family tolerate each other because they understand that the opposition today can become the government tomorrow. Without a norm of toleration for dissent, democracy begins to fray. When a family feud is no longer between members equally deserving of respect but between first- and second-class members, democratic breakdown becomes

\section{Endnotes}

1 "Collectivistic ideologies are inherently authoritarian ..." Liah Greenfeld, Nationalism: Five Roads to Modernity (Cambridge: Harvard University Press, 1992), 11.

2 Peter Baldwin, The Politics of Social Solidarity (New York: Cambridge University Press, 1990).

3 Benedict Anderson, Imagined Communities (New York: Verso, 1991).

4 Ernest Gellner, Nations and Nationalism (Ithaca, NY: Cornell University Press, 1983), 7.

5 Dahl (1971), Bermeo and Yashar (2017).

6 Maya Tudor, The Promise of Power: The Origins of India's Democracy and Pakistan's Autocracy. (Cambridge: Cambridge University Press, 2013). Maya Tudor and Dan Slater, "The Content of Democracy: Nationalist Parties and Inclusive Ideologies in India and Indonesia," in Parties, Movements and Democracy in the Developing World, ed. Nancy Bermeo and Deborah Yashar (New York: Cambridge University Press, 2017).

7 Tudor and Slater, "The Content of Democracy."

8 Donald Horowitz, Ethnic Groups in Conflict (Berkeley: University of California Press, 1985).

9 Anderson, Imagined Communities.

10 Eric Hobsbawm and Terence Ranger, eds., The Invention of Tradition (Cambridge: Cambridge University Press, 1983).

11 Ruth Collier and David Collier, Shaping the Political Arena: Critical Junctures, the Labor Movement and Regime Dynamics in Latin America (Princeton, NJ: Princeton University Press, 1991); James Mahoney, "Path Dependence in Historical Sociology," Theory and Society 29 (2000): 507-548.

12 Gellner, Nations and Nationalism. Jurgen Habermas, "The European Nation State. Its Achievements and Its Limitations. On the Past and Future of Sovereignty and Citizenship," Ratio Juris 9 (2) (1996): 125-137.

13 Anthony Smith, National Identity (Harmondsworth: Penguin, 1991). 
14 National identity, argues Stanley Hoffman, is like an artichoke. It may have many leaves but it also has a core or heart. Stanley Hoffmann, "Obstinate or Obsolete? The Fate of the NationState and the Case of Western Europe," in International Regionalism, ed. Joseph Sonyea (Boston, MA: Little Brown, 1968), 177-230.

15 Przeworksi and Limongi (1997), Boix and Stokes (2003), Boix (2003), Acemoglu and Robinson (2006).

16 Inglehart and Norris (2016).

17 Bermeo and Yashar (2017).

18 Moses Shayo, "A Model of Social Identity with an Application to Political Economy: Nation, Class, and Redistribution," American Political Science Review 103 (2) (2009): 147-174: Matthew Eckel, Inequality, Elite Messaging and National Pride (Georgetown University,), accessed October 3, 2017.

19 Scott Straus, Making and Unmaking Nations: War, Leadership and Genocide in Modern Africa (Ithaca: Cornell University Press, 2015); Edward Miguel. "Tribe or Nation? Nation Building and Public Goods Kenya versus Tanzania,” World Politics 56 (3) (2004): 327-362.

20 Miguel, “Tribe or Nation?”; Prerna Singh, How Solidarity Works for Welfare: Subnationalism and Social Development in India (Cambridge: Cambridge University Press, 2015).

21 Sarah Wallace Goodman, "Conceptualizing and Measuring Citizenship and Integration Policy: Past Lessons and New Approaches,” Comparative Political Studies 48 (14) (2015): 1905-1941.

22 Straus, Making and Unmaking Nations.

23 Rajni Kothari, Politics in India (New Delhi: Orient Longman, 1970).

24 Tudor, Promise of Power, Chapter 3. For a comprehensive analysis of explanations, see Atul Kohli, ed., The Success of India's Democracy (New York: Cambridge University Press, 2001).

25 Winston Churchill, Churchill in his Own Words, ed. Richard Longworth (Ebury Press, 2008).

26 John McLane, Indian Nationalism and the Early Congress (Princeton: Princeton University Press, 1977).

27 Jurgen Habermas, The Structural Transformation of the Public Sphere (Boston: MIT Press, 1989). For an application to how such a transformation was made possible by the nationalist movement in India, see Lloyd I Rudolph and Susanne Hoeber Rudolph, Postmodern Gandhi and Other Essays. (Chicago: University of Chicago Press, 2010).

28 David Anthony Low, Congress and the Raj (Oxford: Oxford University Press, 2006).

29 Thomas Metcalf, Ideologies of the Raj (Cambridge: Cambridge University Press, 1995).

30 Rudolph and Rudolph, Postmodern Gandhi and Other Essays.

31 Samuel Huntington, Political Ordering in Changing Societies (Boston: Beacon, 1968).

32 Tudor, Promise of Power, Chapter 5.

33 Separate electorates set aside seats in provincial and central legislatures for the said community and specified that only that community could vote for the said seats. Reserved electorates also set aside seats for the said community but enabled the entire electorate to vote for those seats. With reserved electorates Congressmen could still mobilize across caste lines by putting up 
an untouchable candidate whereas separate electorates would likely have led lower castes to mobilize separately from Congress altogether.

34 Paul Brass, Language, Religion and Politics in North India (Cambridge: Cambridge University Press, 1974).

35 McLane, Indian Nationalism and the Early Congress, 110-113.

36 All India Congress Committee Papers Nehru Memorial Museum and Library, G-60 of 19451946. August 6-8, 1931.

37 Peter van der Veer, Religious Nationalism: Hindus and Muslims in India (Berkeley: University of California Press, 1994).

38 M.K. Gandhi, Non-Violent Resistance. Manfred Steger, Nonviolent Principles and Nationalist Power (New York: St. Martin's Press, 2000).

39 Mohandas Karamchand Gandhi, Hind Swaraj, 1909.

40 Tudor, Promise of Power, Chapter 5.

41 Kohli, The Success of India's Democracy.

42 yron Weiner, "The Struggle for Equality: Caste in Indian Politics," in The Success of India's Democracy. Kohli, The Success of India's Democracy.

43 Tarunabh Khaitan, "Directive Principles and the Expressive Accommodation of Ideological Dissenters." (paper presented at Oxford University workshop entitled "South Asian Constitutionalism and Constitution.” June 1, 2017).

44 Both citations taken from Constituent Assembly Debates of India, Volume IX, September 13, 1949. Accessed August 29, 2017.

45 Report of the Linguistic Provinces Commission, December 1948, Paragraphs 141 and 152. Central Secretariat Library, New Delhi.

46 Report of the Linguistic Provinces Commission, December 1948, Paragraphs 141 and 152. Central Secretariat Library, New Delhi.

47 Emphasis added. JVP report, for the three members of the committee, Jawaharlal Nehru, Vallabhbhai Patel, and Pattabhi Sitaramayya). Central Secretariat Library, 1949, New Delhi.

48 Ramachandra Guha, "The Battle for Andhra," The Hindu, March 30, 2003. accessed http:// www.thehindu.com/thehindu/mag/2003/03/30/stories/2003033000040300.htm.

49 Ibid.

50 Gary Bass, The Blood Telegram (New York: Knopf Doubleday, 2013).

51 J.A. Naik, The Great Janata Revolution. (New Delhi: S. Chand, 1977), 54-55. Naik is clear that the right to democratic dissent was a key issue in 1977 elections among urban, educated voters but is less clear how important the issue was to rural voters.

52 Sharda Paul, The 1977 General Elections in India. (New Delhi: Associated Publishing House, 1977), 43.

53 Paul, 1977, 46.

54 Myron Weiner, “The 1977 Parliamentary Elections in India,” Asian Survey 17 (7) (1977). 
55 Lloyd and Susanne Rudolph. "India's Election: Backing Into the Future," Foreign Affairs. July 1977. Council on Foreign Relations, 843.

56 Partha Ghosh, BJP and the Evolution of Hindu Nationalism (New Delhi: Manohar, 1999).

57 A history of Hindutva is to be found in Christophe Jaffrelot, ed., Hindu Nationalism: A Reader (Delhi: Permanent Black, 2007).

58 Robin Jeffrey, What's Happening to India? (London: Macmillan, 1986) and Sumantra Bose, Kashmir (Cambridge: Harvard University Press, 2003).

59 Suhas Palshikar, "The BJP and Hindu Nationalism," Journal of South Asian Studies.

60 BBC News, "Timeline: Ayodhya Crisis," accessed January 11, 2018, http://www.bbc.com/ news/world-south-asia-11436552.

61 Thomas Blom Hansen and Christophe Jaffrelot, "Introduction: The BJP After the 1996 Elections," in The BJP and the Compulsions of Politics in India, ed. Thomas Blom Hansen and Christophe Jaffrelot (Delhi: Oxford University Press, 1998), 2-11.

62 Tariq Thachil, Riding the Saffron Wave.

63 BBC News, India's Gujurat Riots: Ten Years On, http://www.bbc.com/news/world-asia-india17176853.

64 Christophe Jaffrelot, “The Modi-centric BJP 2014 Election Campaign: New Techniques and Old Tactics," Contemporary South Asia 23 (2) (2015): 151-166.

65 "Modi Now Says it from Mumbai Billboards: 'I'm a Hindu Nationalist," India Today, July 18, 2013, accessed http://indiatoday.intoday.in/story/modi-now-says-it-from-billboards-im-ahindu-nationalist/1/291857.html.

66 K. Blachand. "Modi Fears a 'Pink Revolution,” The Hindu, ,Accessed_http://www.thehindu. com/news/national/other-states/modi-fears-a-pink-revolution/article5864109.ece.

67 Lisa Trivedi. "Visually Mapping the 'Nation'," Journal of Asian Studies 62 (1) (2003): 11-41.

68 “BJP Election Manifesto 2014,” Accessed_http://www.bjp.org/images/pdf_2014/full_manifesto _english_07.04.2014.pdf.

69 "Sardar Vallabhbhai Patel was Denied his due, Says PM," The Hindu, October 31, 2017, accessed_ http://www.thehindu.com/news/national/previous-governments-ignored-patelslegacy-modi/article19954772.ece.

70 Kanchan Chandra, "Who Is Narendra Modi?," Foreign Affairs, March 30, 2017, accessed https://www.foreignaffairs.com/articles/india/2017-03-30/who-narendra-modi.

71 Siddharth Varadarajan, "Stung by Dalit Backlash, Narendra Modi Eats His Own Words on Cow Slaughter," The Wire, accessed https://thewire.in/57065/stung-by-dalit-backlash-modi-callscow-vigilantes-anti-social/.

72 "India 'Hate Speech' Minister Niranjan Jyoti Keeps Job," BBC News, December 2, 2014, accessed http://www.bbc.com/news/world-asia-india-30326774.

73 http://www.hindustantimes.com/assembly-elections/from-love-jihad-conversion-to-srk-10controversial-comments-by-up-s-new-cm-yogi-adityanath/story-5JW2ZFGZzAdIZeIcj cZCNM.html.

74 M. Lall, "Indian Education Policy under the NDA Government," in Coalition Politics and 
Hindu Nationalism, K. Adeney and L. Saez, ed. (London: Routledge, 2005).

75 Faisal Kutty, "The Disturbing Agenda to Rewrite Indian History,” The Star,, accessed https:// www.thestar.com/opinion/commentary/2016/06/29/the-disturbing-agenda-to-rewrite-indiashistory.html.

76 See for example, Priscilla Clapp, "Securing a Democratic Future for Myanmar." Council on Foreign Relations, Council Special Report No. 75. March 2016.

77 Suhas Palishkar, "The BJP and Hindu Nationalism," Journal of South Asian Studies 38 (4) (2015): 729-732.

78 "The Hanging of Afzal Guru is a Stain on India's Democracy," The Guardian, February 10, 2013, accessed https://www.theguardian.com/commentisfree/2013/feb/10/hanging-afzalguru-india-democracy.

79 "JNU's Journey from 'Prestigious' to 'Anti-national'," December 29, 2016, accessed http://www.thehindu.com/news/cities/Delhi/JNU\%E2\%80\%99s-journey-from\%E2\%80\%98prestigious\%E2\%80\%99-to-\%E2\%80\%98anti-national\%E2\%80\%99/ article16956239.ece.

80 Steve Levitsky and Daniel Ziblatt, How Democracies Die (New York: Crown Press, 2018).

81 "Anti-national Acts: 25 NGOs Lose Foreign Fund Licenses," The Times of India, accessed https://timesofindia.indiatimes.com/india/Anti-national-acts-25-NGOs-lose-foreign-fundlicences/articleshow/55254613.cms

82 "Amnesty International: Fans Arrested in India for Cheering Pakistan Win 'Must Be Freed'," The Guardian, June 21, 2017, Accessed https://www.theguardian.com/sport/2017/jun/21/ amnesty-international-fans-arrested-pakistan-india-cricket-champions-trophy.

83 "AAP Siding with 'Anti-national' Forces," Indian Express, March 28, 2017, Accessed http://indianexpress.com/article/cities/delhi/aap-siding-with-anti-national-forces-bjp-leader4589700/.

84 https://nation.com.pk/08-Jan-2018/four-kashmiris-arrested-for-respecting-pakistanianthem.

85 "Modi's New Mantra: If You are Not With Me, You're Anti-National," The Diplomat, Accessed https://thediplomat.com/2016/02/modis-new-mantra-if-youre-not-with-me-youreanti-national/.

86 "Ex Babus Tell PM Modi Anti-govt is not Anti-national, Stop Religious Divide," Hindustan Times, accessed http://www.hindustantimes.com/india-news/ex-babus-write-to-pm-modi-onrising-nationalism-communalism/story-3ZjNAneXCNqtpfT3wld4JI.html.

87 Juan Linz, The Breakdown of Democratic Regimes (Baltimore: Johns Hopkins University Press, 1978); Levitsky and Ziblatt, How Democracies Die.

88 Dankart Rustow, "Transitions to Democracy,” Comparative Politics 2 (1970). 